\title{
FAKTOR RISIKO LINGKUNGAN KEJADIAN ISPA PADA BALITA DI WILAYAH KERJA PUSKESMAS PANAMBUNGAN
}

\section{ENVIRONMENTAL RISK FACTORS CONCERNING ARI CASES ON TODDLERS IN THE WORKING AREA OF PANAMBUNGAN HEALTH CENTER}

Nur Hamdani Nur
Fakultas Kesehatan
Masyarakat
Universitas Pancasakti
Makassar, Indonesia
email:
hamdani82nur@gmail.
com
Muharti Syamsul
Fakultas Kesehatan
Masyarakat
Universitas Pancasakti
Makassar, Indonesia
email:
muharti.syamsul@gma
il.com
Genoveva Imun
Fakultas Kesehatan
Masyarakat
Universitas Pancasakti
Makassar, Indonesia
email:
geonanu296@ gmail.co
m

PENDAHULUAN

Infeksi saluran pernapasan akut (ISPA) adalah infeksi akut yang menyerang salah satu alveoli. Balita dikatakan ISPA apabila ada tanda dan gejala seperti gejala pilek, batuk dan demam dalam kurun waktu 2 minggu yang diketahui melalui orang tua/pengasuhnya Makassar in 2020.
Abstrak: ISPA merupakan penyakit infeksi akut yang menyerang saluran napas mulai dari hidung sampai dengan alveoli atau kantong paru. Penyakit yang disebabkan oleh berbagai sebab (multifaktorial) ini merupakan penyakit dengan urutan teratas dari sepuluh penyakit terbanyak di Indonesia serta merupakan penyebab terbesar $(17 \%)$ kematian anak di bawah lima tahun. Penelitian ini bertujuan untuk mengetahui faktor risiko lingkungan kejadian ISPA pada balita di wilayah kerja Puskesmas Panambungan. Jenis penelitian menggunakan penelitian analitik observasional desain Cross-Sectional study dengan jumlah sampel sebanyak 88 responden yang diperoleh dengan teknik simple random sampling. Analisis data dilakukan dengan uji chi-square dan besaran risiko dengan nilai odds ratio. Hasil uji statistik menunjukkan bahwa penggunaan obat anti nyamuk bakar $(\mathrm{p}=0,021$; OR 3,573), ventilasi dapur $(\mathrm{p}=0,000$; OR 0,112), kebiasaan merokok anggota keluarga berpengaruh secara signifikan terhadap kejadian ISPA pada balita di wilayah Kerja Puskesmas Panambungan Kota Makassar tahun 2020. Sedangkan variabel ventilasi kamar tidur ( $\mathrm{p}=0,538$; OR 0,570), dan jenis lantai rumah $(\mathrm{p}=0,269$; OR 1,889) tidak berpengaruh secara signifikan terhadap kejadian ISPA pada balita di wilayah kerja Puskesmas Panambungan Kota Makassar tahun 2020.

Kata Kunci: ISPA, Balita, Ventilasi, Obat Nyamuk Bakar, Rokok, Jenis Lantai

Abstract: Acute respiratory infections (ARI) is a disease that attacks one or more parts of the respiratory tract from the nose to the alveoli or lung. This disease which is caused by various factors (multifactorial) is the top rank disease in Indonesia, and is the biggest cause (17\%) of the death of children under five years (toddlers). This study aims to determine the environmental risk factors for the incidence of ARI in children under five in the working area of the Panambungan Health Center. This type of research uses an observational analytic study with a cross-sectional design with a sample of 88 respondents obtained by simple random sampling technique. Data analysis was performed by using chi-square test and the magnitude of the risk with the odds ratio value. The results of statistical tests showed that the use of anti-mosquito coils $(p=0.021 ;$ OR $=3.573)$, kitchen ventilation ( $p=0.000 ;$ OR $=0.112)$, and smoking habits of family members significantly affected ARI cases on toddlers in the working area of Panambungan Health Center, Makassar in 2020. Meanwhile, bedroom ventilation ( $p=0.538$; OR $=0.570)$ and the type of house floor $(p=0.269 ;$ OR $=1.889)$ did not significantly affect ARI cases on toddlers in the working area of Panambungan Health Center,

Keywords: ARI, Toddlers, Ventilation, Mosquito Coils, Smoking, Type of Floor.

(Oktaviani dkk, 2010). Penyakit ini disebabkan oleh berbagai sebab (multifaktorial). Organ saluran pernafasan yang terlibat pada kasus ISPA adalah hidung, laring, tengkorok, brongkus, trakea dan paru-paru. Titik perhatian pemerintah untuk kasus ini begitu tinggi karena tingkat mortalitas yang begitu tinggi terutama 
terjadi akibat radang paru-paru (Widiyano, 2011).

Menurut profil kesehatan Indonesia tahun 2013, infeksi saluran pernapasan akut (ISPA) untuk Provinsi Sulawesi Utara yang terdiagnosis (D) $13,3 \%$ dan terdiagnosis dengan gejala (DG) $24,7 \%$ masih termasuk tinggi dibandingkan dengan Sulawesi Tengah D 8,9\% DG 23,6\%, Sulawesi Selatan D 11,9\% DG 24,9\% Sulawesi Tenggara D13,4\%, DG 22,2\% Gorontalo D 9,5\%, DG 23,2\% Sulawesi Barat D 9,3\% dan DG 20,9\%. (Kusnanto Tapianus Taarelluan, 2016).

Menurut WHO (2013) ASI ekslusif merupakan upaya kekebalan tubuh dan pencegahan dari serangan penyakit. Tingkat risiko kejadian ISPA itu di sebabkan oleh kurangnya pemberian ASI ekslusif pada bayi dan cakupan imunisasi yang rendah. Indonesia adalah negara yang berpenghasilan rendah dan negara ketiga yang memiliki penduduk yang sangat padat (sekitar 250 juta jiwa) di Asia dan sebagai daerah teropis berpotensi menjadi daerah endemik dari beberapa penyakit infeksi yang setiap saat dapat menjadi ancaman bagi kesehatan masyarakat. Penyebab terbesar kematian anak dibawah lima tahun di Indonesia adalah (sekitar 17\%) infeksi saluran pernapasan akut (Shibata, T. Et al, 2014).

Di Indonesia, jumlah kasus infeksi pernapasan akut (ISPA) sangat tinggi dan menempati urutan teratas dari sepuluh penyakit terbanyak. ISPA merupakan masalah kesehatan yang menyebabkan kematian bayi dan balita yang cukup tinggi dimana jumlah tiap tahunnya kejadian ISPA di Indonesia 15000 kasus atau seorang balita meninggal tiap 5 menitnya dan setiap anak diperkirakan mengalami 3-6 episode ISPA setiap tahunnya 40\%-60\% dari kunjungan puskesmas adalah oleh penyakit ISPA. Dari seluruh kematian yang disebabkan ISPA mencakup 20\%-30\%(htt://library.usu.ac.id/fkmrasmaliah.pdf.)

Sedangkan di Kota Makassar menyatakan bahwa kondisi rumah yang padat hunian beresiko 30 kali lebih tinggi untuk mengalami ISPA dibandingkan dengan rumah yang tidak padat penghuninya (Hartati A, 2016).

\section{Infeksi Saluran Pernafasan Akut (ISPA)} merupakan salah satu penyebab utama kematian pada balita didunia. Penyakit ini paling banyak terjadi di negara-negara berkembang di dunia Karena populasi penduduk yang terus bertambah dan tidak terkendali mengakibatkan kepadatan penduduk di suatu wilayah yang tidak tertata baik dari segi aspek sosial, budaya dan kesehatan (Adesanya dan Chiao, 2017).

Infeksi saluran pernapasan akut pada balita dipengaruhi oleh beberapa faktor yaitu gizi yang kurang, status imunisasi yang tidak lengkap, membedong bayi (menyelimuti yang berlebihan), tidak mendapatkan ASI yang memadai, defisiensi vitamin A, kepadatan tempat tinggal, polusi udara akibat asap dapur, orang tua perokok, dan keadaan rumah yang tidak sehat (Riskesdas, 2013). Hasil riset kesehatan dasar (Riskesdas 2018) secara nasional menujukan bahwa prevalensi ISPA 4,4, Sulawesi selatan 2,5 dan Sulawesi barat 2,5. 
Faktor resiko terjadinya ISPA yaitu faktor individu anak, faktor lingkungan, dan faktor perilaku. Faktor individu anak meliputi: umur anak, berat badan lahir, status gizi, vitamin A dan status imunisasi. Faktor lingkungan meliputi: pencemaran udara, dan perilaku merokok, dan kepadatan hunian. Faktor perilaku, dimana apabila faktor perilaku merokok pencegahan dan penanggulangan, ISPA pada bayi dan balita tidak dilakukan dengan benar maka akan menambah resiko terjadinya ISPA (Mariyunani, 2010).

Laporan Dinas Kesehataan Kota Makassar yang bersumber dari bidang pengendalian penyakit dan penyehatan Lingkungan (2019), menunjukkan bahwa penyakit ISPA menjadi penyakit utama nomor 1 di kota Makassar diantara 9 penyakit lainnya dengan jumlah kasus ISPA tahun 2013 sebanyak 53.730, tahun 2014 sebanyak 49.118, tahun 2015 sebanyak 45.569, dan pada tahun 2016 sebanyak 44.819 kasus.

Berdasarkan data kasus infeksi saluran pernapasan akut yang diperoleh peneliti dari Puskesmas Panambungan Kota Makassar angka kejadian ISPA dalam 3 tahun terakhir yaitu: tahun 2017 tercatat sebanyak 212 kasus dengan tidak ada kematian, tahun 2018 tercatat sebanyak 102 dengan tidak ada kematian, tahun 2019 sebanyak 200 kasus dengan tidak ada kematian (Puskesmas Panambungan, 2020).

\section{METODE}

Penelitian ini merupakan penelitian observasional dengan desain cross sectional study. Penelitian ini dilaksanakan pada bulan Oktober Tahun 2020 di Wilayah Kerja Puskesmas Panambungan Kota Makassar. Populasi dalam penelitian ini adalah semua anak balita di Puskesmas Panambungan Kota Makassar yaitu sebanyak 747 balita yang terdiri atas laki-laki sebanya 235 dan perempuan sebanyak 512 orang. Besar sampel yang diambil pada penelitian ini sebanyak 88 responden dengan teknik penarikan sampel yaitu simple rondom sampling. Data diperoleh dengan menggunakan daftar pertanyaan atau kuesioner serta melihat langsung keadaan rumah yang memenuhi syarat kesehatan dan data juga diproleh dari Puskesmas Panambungan Makassar dan instansi yang terkait mengenai judul penelitian serta faktor pustaka yang berkaitan dengan tema penelitian. Instrumen penelitian merupakan alat-alat yang digunakan pada saat pengumpulan data penelitian seperti Lembar kuesioner, alat tulis, kamera dan peneliti itu sendiri. Teknik pengolahan data menggunakan komputer program SPSS kemudian diolah dengan prosedur pengolahan data. Analisis univariat yang di lakukan tiap variabel dari hasil penelitian berupa distribusi frekuensi dan presentase dari tiap variabel dan Analisis bivariat yang dilakukan terhadap dua variabel yang digunakan berpengaruh dengan tabulasi silang diantara semua variabel dependent dan variabel independent dengan metode chi-square. 


\section{HASIL DAN DISKUSI}

\section{Karakteristik Responden}

Tabel 1 menunjukkan bahwa dari 88 $(100 \%)$ responden, paling banyak responden dengan tingkat pendidikan tamatan SMA/sederajat sebanyak $40(45.5 \%)$ dan paling sedikit dengan tingkat pendidikan perguruan tinggi yaitu $7(8,0 \%)$ responden. Distribusi pekerjaan responden dari dari 88 (100\%) responden, paling banyak responden dengan jenis pekerjaan sebagai ibu rumah tangga yaitu sebanyak $80 \quad(90.9 \%)$ dan sisanya bekerja sebagai karyawan swasta dan wiraswasta yaitu masing-masing $4(4.5 \%)$ responden.

Jenis kelamin balita, dari 88 (100\%) balita terdapat $46(52.3 \%)$ balita berjenis kelamin perempuan dan sisanya berjenis kelamin lakilaki yaitu sebanyak $42 \quad(47.7 \%)$ balita. Berdasarkan umur balita, dari $88(100 \%)$ balita paling banyak dengan rentan umur $1-2$ tahun yaitu sebanyak $74(84,1 \%)$ balita dan sisanya sebanyak $14(15,9 \%)$ balita dengan rentang umur 3 - 5 tahun.

Tabel 1

Karakteristik Responden

\begin{tabular}{lcc}
\hline \multicolumn{1}{c}{ Karakteristik } & $\mathrm{n}$ & $\%$ \\
\hline Pendidikan & 9 & 10,2 \\
Tamat SD/sederajat & 32 & 36,4 \\
Tamat SMP/sederajat & 40 & 45,5 \\
Tamat SMA/sederajat & 7 & 8,0 \\
Perguruan Tinggi & & \\
Pekerjaan & 80 & 90,9 \\
Ibu Rumah Tanggah & 4 & 4,5 \\
Karyawan Swasta & 4 & 4,5 \\
$\quad$ Wiraswasta & & \\
Jenis Kelamin bayi & 46 & 52,3 \\
Perempuan & 42 & 47,7 \\
Laki-laki & & \\
Umur balita & 74 & 84,1 \\
1 - 2 tahun & 14 & 15,9 \\
$3-5$ tahun & & \\
Berat badan balita & 10 & 11,4 \\
$6,0-8,1$ & 24 & 27,3 \\
$8,2-10,3$ & 23 & 26,1 \\
$10,4-12,5$ &
\end{tabular}

$\begin{array}{lcc}12,6-14,7 & 22 & 25,0 \\ 14,8-16,9 & 7 & 8,0 \\ 17,0-19,1 & 2 & 2,3 \\ 65-72,5 & & \\ 72,6-80,1 & 5 & 5,7 \\ 80,2-87,7 & 24 & 27,3 \\ 87,8-95,3 & 27 & 30,7 \\ 95,4-102,9 & 21 & 23,9 \\ 103,0-110,5 & 8 & 9,1 \\ \text { mlah } & 3 & 3,4 \\ & 88 & 100\end{array}$

Sumber: Data Primer, 2020

Berdasarkan kelas interval berat badan balita, dari 88 (100\%) balita paling banyak berat badan balita dengan rentang 8,2 - 10,3 Kg yaitu sebanyak $24(27,3 \%)$ balita dan paling sedikit berada pada rentang 17,1-19,1 Kg yaitu sebanyak $2(2,3 \%)$ balita. tinggi badan balita, dari $88(100 \%)$ balita paling banyak dengan rentang tinggi badan $80,2-87,7 \mathrm{~cm}$ yaitu sebanyak $27(30,7 \%)$ balita dan paling sedikit dengan rentang tinggi badan 103,0 $-110,5 \mathrm{~cm}$ yaitu sebanyak $3(3,4 \%)$ balita.

\section{Analisis Univariat}

Tabel 2

Distibusi Variabel Penelitian

\begin{tabular}{lcc}
\hline \multicolumn{1}{c}{ Variabel } & $\mathrm{n}$ & $\%$ \\
\hline Kejadian ISPA pada balita & 32 & 36,4 \\
Ya & 56 & 63,6 \\
Tidak & & \\
Ventilasi kamar tidur & 84 & 95,5 \\
$\quad$ Memenuhi Syarat & 4 & 4,5 \\
Tidak Memenuhi Syarat & & \\
Penggunan obat nyamuk bakar & 22 & 25,0 \\
Ya & 66 & 75,0 \\
Tidak & & \\
Ventilasi dapur & 17 & 19,3 \\
$\quad$ Memenuhi Syarat & 71 & 80,7 \\
Tidak Memenuhi Syarat & & \\
Jenis lantai rumah & 78 & 88,6 \\
$\quad$ Memenuhi Syarat & 10 & 11,4 \\
Tidak Memenuhi Syarat & & \\
Kebiasaan anggota keluarga & & \\
merokok dalam rumah & 20 & 22,7 \\
Ya & 68 & 77,3 \\
Tidak & 88 & 100 \\
Total & & \\
Sumber: Data Primer, 2020 &
\end{tabular}

Berdasarkan Tabel 2 diketahui bahwa dari $88(100 \%)$ balita, terdapat sebanyak $32(46,4 \%)$ 
balita mengalami ISPA dan sebanyak 56 $(63,6 \%)$ balita yang tidak mengalami ISPA. ventilasi kamar tidur responden paling banyak telah memenuhi syarat yaitu sebanyak 84 $(95,5 \%)$ responden dan yang tidak memenuhi syarat yaitu sebanyak $4(4,5 \%)$ responden.

Responden paling banyak tidak menggunakan obat nyamuk bakar yaitu sebanyak $66(75,0 \%)$ responden dan yang menggunakan obat nyamuk bakar sebanyak 22 $(25,0 \%)$ responden. Ventilasi dapur responden paling banyak tidak memenuhi syarat yaitu sebanyak $71(80,7 \%)$ responden dan yang telah memenuhi syarat yaitu sebanyak 17 (19,3\%) responden. Jenis lantai rumah responden paling banyak telah memenuhi syarat yaitu sebanyak $78(88,6 \%)$ responden dan paling sedikit yang tidak memenuhi syarat yaitu sebanyak 10 $(11,4 \%)$. Dari $88(100 \%)$ responden terdapat 20 $(22,7 \%)$ responden yang memiliki anggota keluarga dengan kebiasaan merokok dalam rumah dan selebihnya yaitu sebanyak 68 $(77,3 \%)$ responden tidak memiliki anggota keluarga dengan kebiasaan merokok dalam rumah (Tabel 2).

\section{Analisis Bivariat}

Berdasarkan Tabel 3 menunjukan bahwa dari $4(4,5 \%)$ responden dengan ventilasi kamar tidur yang tidak memenuhi syarat, sebanyak 1 $(1,1 \%)$ responden mengalami ISPA pada balita, dan $3(3,4 \%)$ responden tidak mengalami ISPA pada balita. Sedangkan dari 84 (95,5\%) responden dengan ventilasi kamar tidur yang memenuhi syarat, sebanyak $31 \quad(35,2 \%)$ responden mengalami ISPA pada balita dan sebanyak $53 \quad(60,2 \%)$ responden tidak mengalami ISPA pada balita.

Hasil analisis statistik menunjukkan nilai $p$-value $=0,538>0,05$ yang berarti ventilasi kamar tidur responden tidak berpengaruh secara signifikan terhadap kejadian ISPA pada balita di Wilayah Kerja Puskesmas Panambungan Kota Makassar Tahun 2020.

Diketahui dari $22(25,0 \%)$ responden yang menggunakan obat anti nyamuk bakar, sebanyak $13(14,8 \%)$ responden mengalami ISPA pada balita dan sebanyak $9(10,2 \%)$ responden tidak mengalami ISPA pada balita. Sedangkan dari $66(75,0 \%)$ responden yang tidak menggunakan obat anti nyamuk bakar, sebanyak $19(21,6 \%)$ responden mengalami ISPA pada balita, dan $47(53,4 \%)$ responden tidak mengalami ISPA pada balita. Hasil analisis statistik menunjukkan nilai $p$-value $=$ $0,021<0,05$ yang berarti penggunaan obat anti nyamuk bakar berpengaruh secara signifikan terhadap kejadian ISPA pada balita di Wilayah Kerja Puskesmas Panambungan Kota Makassar Tahun 2020. Nilai Odds Ratio (OR) diperoleh yaitu 3,573 yang berarti bahwa responden yang menggunakan obat anti nyamuk bakar berisiko 3,6 kali lebih besar mengalami ISPA pada balita dibandingkan responden yang tidak menggunakan obat anti nyamuk bakar.

\section{Tabel 3}

\begin{tabular}{|c|c|c|c|c|c|c|c|}
\hline Analis & & $\begin{array}{r}\text { unga } \\
\mathbf{K}\end{array}$ & $\begin{array}{l}\text { Var } \\
\text { adia }\end{array}$ & $\begin{array}{l}\text { el I } \\
\text { ISP }\end{array}$ & & & igan \\
\hline Variabel & & Kejad & ISP & & & & \\
\hline Penelitian & & $\mathrm{Ya}$ & & & & & $(O R)$ \\
\hline & $\mathrm{n}$ & $\%$ & $\mathrm{n}$ & $\%$ & $\mathrm{n}$ & $\%$ & \\
\hline $\begin{array}{l}\text { Ventilasi } \\
\text { Kamar }\end{array}$ & & & & & & & \\
\hline MS & 31 & 35,2 & 53 & 60,2 & 84 & 95,5 & 0,538 \\
\hline $\begin{array}{l}\text { TMS } \\
\text { Penggunaa }\end{array}$ & 1 & 1,1 & 3 & 3,4 & 4 & 4,5 & $(0,570)$ \\
\hline
\end{tabular}


lantai rumah memenuhi syarat, sebanyak 27

Bakar

$\begin{array}{llllllll}\text { Ya } & 13 & 14,8 & 9 & 10,2 & 22 & 25,0 & 0,021\end{array}$

$\begin{array}{llllllll}\text { Tidak } & 19 & 21,6 & 47 & 53,4 & 66 & 75,0 & (3,573)\end{array}$

Ventilasi

Dapur

$\begin{array}{llllllll}\text { MS } & 13 & -14,8 & 4 & 4,5 & 17 & 19,3 & 0,000\end{array}$

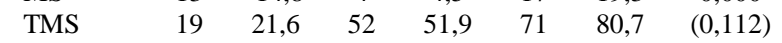

Jenis Lantai

$\begin{array}{cccccccc}\text { Rumah } & & & & & & & \\ \text { MS } & 27 & -30,7 & 51 & 58,0 & 78 & 88,6 & 0,269\end{array}$

$\begin{array}{llllllll}\text { TMS } & 5 & 5,7 & 5 & 5,7 & 10 & 11,4 & (1,889)\end{array}$

Kebiasaan

Merokok

$\begin{array}{llllllll}\text { Ya } & 16 & -18,2 & 4 & 4,5 & 20 & 22,7 & 0,000\end{array}$

\begin{tabular}{llllllll} 
Tidak & 16 & 18,2 & 52 & 59,1 & 68 & 77,3 & $(13,000)$ \\
\hline Total & 32 & 36,5 & 56 & 63,6 & 88 & 100 & \\
\hline
\end{tabular}

Sumber: Data Primer, 2020

Dari $71(80,7 \%)$ responden dengan ventilasi dapur yang tidak memenuhi syarat, sebanyak $19(21,6 \%)$ responden mengalami ISPA pada balita, dan $52(59,1 \%)$ responden tidak mengalami ISPA pada balita. Sedangkan dari $17(19,3 \%)$ responden dengan ventilasi dapur yang memenuhi syarat, sebanyak 13 $(14,8 \%)$ responden mengalami ISPA pada balita dan sebanyak $4 \quad(4,5 \%)$ responden tidak mengalami ISPA pada balita.

Hasil analisis statistik menunjukkan nilai p-value $=0,000<0,05$ yang berarti bahwa ventilasi dapur berpengaruh secara signifikan terhadap kejadian ISPA pada balita di Wilayah Kerja Puskesmas Panambungan Kota Makassar Tahun 2020. Nilai Odds Ratio (OR) diperoleh yaitu 0,112 yang berarti bahwa responden yang memiliki ventilasi dapur tidak memenuhi syarat berisiko 0,1 kali mengalami ISPA pada balita dibandingkan responden yang memiliki ventilasi dapur yang memenuhi syarat.

Dari $10(11,4 \%)$ responden yang memiliki jenis lantai rumah tidak memenuhi syarat, sebanyak $5(5,7 \%)$ responden mengalami ISPA pada balita dan sebanyak $5(5,7 \%)$ responden tidak mengalami ISPA pada balita. Sedangkan dari $78(88,6 \%)$ responden yang memiliki jenis
$(30,7 \%)$ responden mengalami ISPA pada balita, dan $51 \quad(58,0 \%)$ responden tidak mengalami ISPA pada balita.

Hasil analisis statistik menunjukkan nilai p-value $=0,269>0,05$ yang berarti bahwa jenis lantai rumah tidak berpengaruh secara signifikan terhadap kejadian ISPA pada balita di Wilayah Kerja Puskesmas Panambungan Kota Makassar Tahun 2020. Nilai Odds Ratio (OR) diperoleh yaitu 1,889 yang berarti bahwa responden yang memiliki jenis lantai rumah tidak memenuhi syarat tetap berisiko 1,9 kali lebih besar mengalami ISPA pada balita dibandingkan responden yang memiliki jenis lantai rumah memenuhi syarat.

Berdasarkan kebiasaan merokok anggota keluarga, diketahui bahwa dari 20 (22,7\%) responden yang memiliki anggota keluarga merokok dalam rumah, sebanyak 16 (18,2\%) responden mengalami ISPA pada balita dan sebanyak 4 (4,5\%) responden tidak mengalami ISPA pada balita. Sedangkan dari 68 (77,3\%) responden yang tidak memiliki anggota keluarga merokok dalam rumah, sebanyak 16 $(18,2 \%)$ responden mengalami ISPA pada balita, dan $52(59,1 \%)$ responden tidak mengalami ISPA pada balita.

Hasil analisis statistik menunjukkan nilai p-value $=0,000<0,05$ yang berarti bahwa kebiasaan anggota keluarga merokok dalam rumah berpengaruh secara signifikan terhadap kejadian ISPA pada balita di Wilayah Kerja Puskesmas Panambungan Kota Makassar Tahun 2020. Nilai Odds Ratio (OR) diperoleh yaitu 
13,000 yang berarti bahwa responden yang memiliki anggota keluarga merokok dalam rumah berisiko 13 kali lebih besar mengalami ISPA pada balita dibandingkan responden yang tidak memiliki anggota keluarga merokok dalam rumah.

\section{Pengaruh Ventilasi Kamar Tidur Terhadap Kejadian ISPA Pada Balita}

Ventilasi kamar tidur merupakan lubang angin yang berada di kamar tidur dan berfungsi untuk proses pengantian udara pada kamar dimana udara segar diharapkan masuk ke dalam kamar tidur dan mengeluarkan udara kotor dari kamar tidur secara alamiah maupun buatan. Pengukuran luas ventilasi kamar pada penelitian ini dilakukan dengan mengukur panjang dan lebar tiap-tiap ventilasi yang ada dikamar kemudian dikalikan untuk memperoleh luas ventilasi kamar tidur. Hasil perhitungan luas seluruh ventilasi selanjutnya dibandingkan dengan luas lantai kamar tidur responden. Luas ventilasi kamar tidur yang $\geq 10 \%$ dari luas lantai kamar tidur dimasukkan sebagai kategori memenuhi syarat, dan luas ventilasi kamar tidur yang $<10 \%$ luas lantai kamar tidur dimasukkan sebagai kategori tidak memenuhi syarat.

Hasil penelitian menunjukkan bahwa 84 $(95,5 \%)$ responden yang memiliki ventilasi kamar tidur yang telah memenuhi syarat yaitu $\geq$ $10 \%$ dari luas lantai kamar tidur. Jumlah ini lebih banyak dibandingkan dengan jumlah ventilasi kamar tidur yang tidak memenuhi syarat yaitu $<10 \%$ luas lantai, namun masih terdapat banyak responden yang memiliki balita yang mengalami ISPA yaitu sebanyak 31
$(35,2 \%)$ balita. Hasil uji bivariat menggunakan uji Fisher's Exact Test menunjukkan bahwa nilai $p$-value $=0,583>0,05$ atau Ho diterima yang berarti bahwa ventilasi kamar tidur tidak berpengaruh secara signifikan terhadap kejadian ISPA pada Balita di wilayah kerja Puskesmas Panambungan Kota Makassar tahun 2020.

Hasil penelitian ini sejalan dengan penelitian yang dilakukan Ningrum E K (2015) yang menunjukkan bahwa tidak terdapat hubungan yang signifikan antara ventilasi kamar tidur dengan kejadian ISPA non pneumonia pada Balita di wilayah kerja Puskesmas Sungai Pinang $(p$-value $=0,213>0,05)$. Demikian juga dengan penelitian yang dilakukan Zairinayanti dan Putri D H (2020) tentang luas ventilasi rumah susun Palembang. Hasil uji statistik menggunakan uji chi-square menunjukkan $p$ value $=1,000>0,05$ yang berarti bahwa tidak terdapat hubungan yang signifikan antara luas ventilasi dengan kejadian ISPA.

Banyaknya balita yang mengalami ISPA meskipun telah memiliki vantilasi kamar tidur yang memenuhi syarat, dikarenakan ventilasi bukan merupakan faktor risiko utama kejadian ISPA pada balita. Berdasarkan hasil pengamatan peneliti, kejadian ISPA pada balita di wilayah kerja Puskesmas Panambungan Kota Makassar banyak disebabkan oleh perilaku merokok anggota keluarga yaitu dilihat dari banyaknya responden yang memiliki anggota keluarga yang merokok dalam rumah. Ventilasi kamar tidur yang baik atau memenuhi syarat berfungsi sebagai jalur sirkulasi udara kamar sehingga bahan pencemar udara dalam kamar 
seperti asap rokok dapat keluar dan diganti dengan udara segar dari luar. Selain itu, kamar yang tidak memiliki ventilasi yang cukup dapat menyebabkan pencahayaan alami kamar kurang baik dan suhu udara kamar menjadi lembab sehingga meningkatkan pertumbuhan mikroorganisme pencemar udara yang dapat menyebabkan terjadinya ISPA pada Balita. Hasil penelitian berbeda ditemukan Dewi C.A (2012) yang menunjukkan bahwa terdapat hubungan antara luas ventilasi kamar tidur dengan kejadian ISPA pada balita di wilayah kerja Puskesmas Gayamsari (p-value $=0,047<$ 0,05). Hasil penelitian ini juga menunjukkan hasil yang sama dengan temuan peneliti yang menunjukkan bahwa jumlah ventilasi kamar tidur responden yang memenuhi syarat lebih banyak dari banyaknya ventilasi kamar tidur responden yang tidak memenuhi syarat.

\section{Pengaruh Penggunaan Obat Nyamuk Bakar Terhadap Kejadian ISPA Pada Balita}

Obat anti nyamuk bakar merupakan salah satu obat anti nyamuk yang banyak digunakan responden sebagai salah satu cara mengusir nyamuk yang ada didalam rumah. Namun sebaiknya kebiasaan ini harus dihindari karena cara mengusir nyamuk dengan menggunakan obat anti nyamuk bakar dapat menghasilkan debu dan asap yang tentu saja bisa mengganggu kesehatan. Hasil penelitian menunjukkan bahwa terdapat $22(25,0 \%)$ responden menggunakan obat anti nyamuk bakar, sebanyak $13(14,8 \%)$ responden yang memiliki balita mengalami ISPA dan sebanyak $9(10,2 \%)$ responden yang tidak mengalami ISPA pada balita. Hasil uji bivariat menggunakan uji chi-square diketahui nilai $p$-value sebesar $0,021<0,05$ sehingga yang berarti Ho ditolak yang artinya bahwa obat anti nyamuk bakar berpengaruh secara signifikan terhadap kejadian ISPA pada balita di wilayah kerja Puskesmas Panambungan Kota Makassar tahun 2020. Nilai Odds Ratio (OR) diperoleh sebesar 3,573 yang berarti bahwa responden yang menggunakan obat anti nyamuk bakar memiliki risiko 3,6 kali lebih besar untuk mengalami ISPA pada balita dibandingkan dengan responden yang tidak menggunakan obat anti nyamuk bakar.

Hasil penelitian ini sejalan dengan penelitian yang dilakukan Saleh M.G dan Aeni. S (2017) yang menunjukkan bahwa terdapat hubungan yang bermakna antara penggunaan obat anti nyamuk yang tidak memenuhi syarat dengan kejadian ISPA pada balita di Wilayah Kerja Puskesmas Dahlia Kecamatan Mariso. Hasil ini juga sejalan dengan hasil penelitian yang dilakukan oleh Saputra S (2017) tentang hubungan penggunaan obat anti nyamuk bakar dengan kejadian ISPA pada balita menggunakan desain penelitian Case Control. Hasil penelitian tersebut menunjukkan bahwa terdapat hubungan signifikan antara pemakaian obat anti nyamuk bakar dengan kejadian ISPA pada balita di Puskesmas Pengandang Kabupaten Lombok Tengah $(\mathrm{p}$ value $=0,001<0,05)$.

Dari hasil pengamatan peneliti, dari 66 $(75,0 \%)$ responden yang tidak menggunakan obat anti nyamuk bakar namun memiliki balita yang mengalami ISPA yaitu sebanyak 19 $(21,6 \%)$ karena responden memiliki anggota 
keluarga yang merokok dalam rumah sehingga menjadi pemicu terjadinya ISPA pada balita dan juga karena umumnya responden tidak memiliki ventilasi dapur yang memenuhi syarat sehingga asap hasil dari proses masak di dapur terkurung dalam rumah dikarenakan rata-rata ruang dapur responden terhubung atau tersambung dengan ruang lainnya. Selain itu terdapat responden yang menggunakan obat anti nyamuk bakar namun tidak mengalami ISPA pada balita dikarenakan responden memiliki ventilasi rumah yang baik atau memenuhi syarat sehingga asap yang berasal dari obat anti nyamuk bakar dapat dengan mudah keluar dari ruangan kamar.

\section{Pengaruh Ventilasi Dapur Terhadap Kejadian ISPA Pada Balita}

Ventilasi dapur adalah ventilasi yang harus dimiliki setiap rumah agar udara/asap dari dapur dapat teralirkan keluar rumah. Ventilasi dapur yang tidak memenuhi syarat dapat menyebabkan udara/asap dari dari dapur akan terkurung dalam rumah sehingga dapat menyebabkan kejadian ISPA pada balita. Hasil peneliian menunjukkan bahwa dari 17 (19,3\%) responden yang memiliki ventilasi dapur yang memenuhi syarat, sebanyak $13 \quad(14,8 \%)$ responden yang mengalami ISPA pada balita sedangkan $4(4,5 \%)$ responden tidak mengalami ISPA pada balita.

Hasil uji bivariat menggunakan uji chisquare diketahui nilai $p$-value sebesar $0,000<$ 0,05 sehingga berarti Ho ditolak, yang artinya bahwa ventilasi dapur berpengaruh secara signifikan terhadap kejadian ISPA pada balita di wilayah kerja Puskesmas Panambungan Kota Makassar tahun 2020. Nilai Odds Ratio (OR) diperoleh sebesar 0,112 yang berarti bahwa responden yang memiliki ventilasi dapur tidak memenuhi syarat berisiko 0,1 kali mengalami ISPA pada balita dibandingkan dengan responden yang memiliki ventilasi dapur memenuhi syarat.

Penelitian ini sejalan dengan penelitian yang dilakukan oleh Sudirman dkk (2020) yang menunjukkan bahwa terdapat hubungan antara luas ventilasi dengan kejadian ISPA pada balita $(p$-value $=0,004<0,05)$. Selain itu, penelitian tersebut juga menunjukkan bahwa selain faktor luas ventilasi, faktor jenis bahan bakar yang digunakan juga berhubungan dengan kejadian ISPA pada balita $(p$-value $=0,000<0,05)$. Asap dapur dapat menyebabkan gangguan pernapasan. Pembakaran yang terjadi di dapur rumah menjadi sumber pengotoran atau pencemaran udara. Pengaruh kesehatan akan tampak apabila kadar zat pengotor meningkat sehingga timbul penyakit. Pengaruh zat kimia ini pertama-tama akan timbul pada sistem pernapasan dan kulit serta selaput lendir, selanjutnya apabila zat pencemar masuk keperedaran dara maka efek sistemik tidak dapat dihindari.

\section{Pengaruh Jenis Lantai Rumah Terhadap Kejadian ISPA Pada Balita}

Jenis lantai rumah yang baik adalah jenis lantai yang kedap air dan mudah dibersihkan, dan paling tidak lantai perlu diplester, dan akan lebih baik jika dilapisi keramik yang mudah dibersihkan. Selain itu, lantai rumah juga dalam 
keadaan kering dan tidak lembab yang tidak memenuhi standar atau lembab merupakan media yang baik untuk perkembangbiakkan bakteri dan virus penyebab penyakit termasuk penyakit ISPA pada balita.

Hasil peneliian ini menunjukkan bahwa mayoritas responden telah menggunakan jenis lantai yang memenuhi syarat yaitu sebanyak 78 $(88 \%)$ responden, $27 \quad(30,7)$ responden diantaranya mengalami kejadian ISPA pada balita sedangkan yang tidak mengalami ISPA pada balita sebanyak $51(58,0 \%)$ responden. Hasil uji bivariat menggunakan uji chi-square diketahui nilai $p$-value sebesar 0,269>0,05 sehingga berarti Ho diterima, yang artinya bahwa jenis lantai rumah tidak berpengaruh secara signifikan terhadap kejadian ISPA pada balita di wilayah kerja Puskesmas Panambungan Kota Makassar tahun 2020. Sejalan dengan penelitian yang dilakukan Winardi $\mathrm{W}$ dkk (2015) yang menunjukkan Ha ditolak yang artinya tidak ada hubungan antara jenis lantai rumah dengan penyakit ISPA pada balita ( $p$ value $=0,895>0,05)$. Dimana hasil penelitian tersebut juga menunjukkan karakter responden yang sama yaitu mayoritas telah menggunakan jenis lantai rumah yang memenuhi syarat (berlapis keramik).

Hasil penelitian Safrisal S.A (2017) yang dilakukan di Gampong Blang Muko Kecamatan Kuala Kabupaten Nagan Raya menemukan bahwa rata-rata lantai rumah responden berupa lantai semen yang tidak diplaster dan lantai dari tanah, sehingga pada saat musim kemarau akan menghasilkan debu. Lantai yang terbuat dari semen rata-rata sudah rusak dan tidak kedap air, lantai berdebu dan lembab sehingga berdampak mingkatkan kejadian ISPA pada balita. Berbeda dengan penelitian Toanabun (2003) yang mengadakan penelitian di Desa Tual, Kecamatan Kei Kecil, Kabupaten Maluku Tenggara yang menujukkan bahwa terdapat hubungan antara lantai dengan kejadian ISPA pada balita.

\section{Pengaruh Kebiasaan Anggota Keluarga Merokok Terhadap Kejadian ISPA Pada Balita}

Rokok merupakan salah satu produk industri yang mengandung sekitar 3.000 bahan kimiawi. Unsur-unsur kimia yang penting pada rokok antara lain: tar, nikotin, benzopryirn, metilkloride, aseton, amonia, dan karbon monoksida. Sekitar $1-5 \%$ dari asap rokok mengandung karbon monoksida yang berbahaya bagi kesehatan utamanya yang berkaitan dengan saluran pernafasan. Kebiasaan anggota keluarga yang merokok dalam rumah, dapat menyebabkan pencemaran udara dalam rumah sehingga dapat berdampak pada kejadian ISPA balita (Bustan, 2015).

Hasil penelitian ini menunjukkan bahwa dari $20(22,7 \%)$ responden yang memiliki anggota keluarga merokok dalam rumah, sebanyak $16(18,2 \%)$ responden mengalami ISPA pada balita dan 4 (4,5\%) responden tidak mengalami ISPA pada balita. Hasil uji bivariat menggunakan uji chi-square diketahui nilai $p$ value sebesar $0,000<0,05$ sehingga berarti Ho ditolak, yang artinya bahwa kebiasaan anggota keluarga yang merokok dalam rumah 
berpengaruh secara signifikan terhadap kejadian

ISPA pada balita di wilayah kerja Puskesmas Panambungan Kota Makassar tahun 2020. Nilai Odds Ratio (OR) diperoleh sebesar 13,000 yang berarti bahwa responden yang memiliki anggota keluarga yang merokok dalam rumah berisiko 13 kali lebih besar untuk mengalami ISPA pada balita dibandingkan dengan responden yang tidak memiliki anggota keluarga merokok dalam rumah.

Hasil penelitian ini sejalan dengan penelitian yang dilakukan Winardi W dkk (2015) yang menunjukkan bahwa ada hubungan antara status merokok di dalam rumah dengan kejadian ISPA pada balita di wilayah kerja Puskesmas Sario Kecamatam Sario Kota Manado ( $p$-value $=0,001<0,05 ;$ OR 7,091) Hasil analisis multivariat pada penelitian ini juga menunjukkan bahwa status merokok di dalam rumah merupakan faktor dominan kejadian ISPA pada balita dibandingkan dari beberapa faktor yang berhubungan yaitu kepadatan hunian, ventilasi dan keberadaan hewan peliharaan.

Hasil penelitian yang sama juga ditemukan Ramadhaniyanti N.G, dkk (2015) yang melakukan penelitian tentang faktor risiko lingkungan rumah dan perilaku yang berhubungan dengan kejadian ISPA pada balita di Kelurahan Kuningan Kecamatan Semarang Utara yang menunjukkan bahwa anggota keluarga yang merokok di dalam rumah beresiko 4,219 kali untuk menderita ISPA dari pada keluarga yang tidak memiliki angota keluarga merokok di dalam rumah.

\section{KESIMPULAN}

Berdasarkan hasil penelitian dan pembahasan tentang Faktor Risiko Lingkungan Kejadian ISPA pada Balita di Wilayah Kerja Puskesmas Panambungan Kota Makassar Tahun 2020 maka dapat ditarik kesimpulan bahwa tidak ada pengaruh ventilasi kamar tidur dengan Kejadian ISPA pada Balita di Wilayah Kerja Puskesmas Panambungan Kota Makassar Tahun 2020, ada pengaruh kebiasaan menggunakan obat anti nyamuk bakar terhadap Kejadian ISPA pada Balita di Wilayah Kerja Puskesmas Panambungan Kota Makassar Tahun 2020, ada pengaruh ventilasi dapur terhadap Kejadian ISPA pada Balita di Wilayah Kerja Puskesmas Panambungan Kota Makassar Tahun 2020, tidak ada pengaruh jenis lantai rumah terhadap Kejadian ISPA pada Balita di Wilayah Kerja Puskesmas Panambungan Kota Makassar Tahun 2020 dan ada pengaruh kebiasaan merokok orang tua dalam rumah terhadap Kejadian ISPA pada Balita di Wilayah Kerja Puskesmas Panambungan Kota Makassar Tahun 2020. Oleh karena itu, disarankan kepada masyarakat agar lebih peduli dan memperhatikan syarat dari rumah sehat tentang ventilasi dapur, kebiasaan menggunakan obat anti nyamuk bakar dan juga kebiasaan merokok dalam rumah. Serta diharapakan kepada petugas kesehatan agar lebih intensif dalam memberikan penyuluhan atau sosialisasi tentang lingkungan rumah yang sehat guna mencegah terjadinya penyakit ISPA khususnya pada balita 


\section{REFERENSI}

Agungnisa A, (2019). Faktor Sanitasi Fisik Rumah yang Berpengaruh Terhadap Kejadian ISPA pada Balita di Desa Kalianget Timur, Jurnal Kesehatan Lingkungan, 11(1), 1-9.

Alahudin M, Jayadi, (2014). Kondisi Lingkungan Sekitar Terhadap Kenyamanan Termal Rumah Sewa. Jurnal Ilmiah Anim Ha,1(3).

Bustan, (2015). Manajemen Pengendalian Penyakit Tidak Menular. Jakarta: PT. Rineka Cipta.

Dewi, C Angelina. (2012). Hubungan Kondisi Lingkungan Fisik Rumah Dengan Krjadian ISPA pada Balita Di Wilayah Kerja Puskesmas Gayamsari Kota Semarang. Jurnal Kesehatan Masyarakat, 1(2).

Dinas Kesehatan Kota Makassar, Laporan Data Kasus ISPA Tahun 2013-2016

Dongky P dan Kadriyanti, (2016). Faktor Risiko Lingkungan Fisik Rumah dengan Kejadian ISPA Balita.di Kelurahan Takatidung Polewali Mandar. Jurnal of Public Health, 5(4).

Hayati S, (2014). Gambaran Faktor Penyebab Infeksi Saluran Pernafasan Akut. Jurnal Ilmu Keperawatan, 11(1).

Jayanti I.D, Ashar T, dan Aulia D, (2017). Pengaruh Lingkungan Rumah Terhadap ISPA Balita di Wilayah Kerja Puskesmas Tanjung Haloban Kabupaten Labuan Batu. Jurnal Jumantik, 3(2).

Kartini K, dkk. (2020). Hubungan Antara Perilaku Orang Tua Tentang Infeksi Saluran Pernapasan Akut (ISPA) Dengan Kekambuhan ISPA Pada Balita di Wilayah Kerja UPTD Puskesmas Wukir. Jurnal Promotif Preventif, 2(2), 27-34.

Kartini K, Nur HN, Asaskas A. (2019). Pengaruh Kondisi Fisik Rumah Dengan
Kejadian ISPA Pada Anak Usia 1-12 Tahun di Wilayah Kerja Puskesmas Tarakan Kota Makassar. Jurnal Promotif Preventif, 1(2), 1-9.

Putra A.N, (2015). Hubungan Kualitas Sanitasi Rumah Dengan Kejadian Infeksi Saluran Pernafasan Akut di Puskesmasa IV Denpasar Selatan Kota Denpasar. 9(2), 1907-5626.

Puteri, D Ade, (2017). Analisis Faktor yang Berhubungan dengan Kondisi Rumah Sehat di Desa Bandur Picak Kecamatan Kota Kampar Hulu. Jurnal Kesehatan Masyarakat, 1(2).

Dinas Kesehatan Kota Makassar, (2019). Laporan ISPA Dinkes Kota Makassar.

Marayunani, (2010). Ilmu Kesehatan Anak Dalam Kebidanan. Jakarta.

Medhyna, (2019). Hubungan Lingkungan Fisik Rumah dengan Kejadian ISPA pada Balita, 1(2).

Milo, S. dan Ismanto Y. (2015). Hubungan Kebiasaan Merokok Di Dalam Rumah Dengan Kejadian ISPA Pada Anak 1-5 tahun. Di Puskesmas Sario Kota Manado, 3(2).

Ningrum E K, (2015). Hubungan Kondisi Fisik Rumah Dan Kepadatan Hunian Dengan Kejadian Ispa Non Pneumonia Pada Balita Di Wilayah Kerja Puskesmas Sungai Pinang. Jurnal Publikasi Kesehatan Masyarakat , 2(2), 72 - 76.

Notoatmodjo, S. (2010). Metodologi Penelitian Kesehatan. Jakarta.

Oktaviani dkk, (2010). Hubungan Kondisi Fisik Rumah dan Perilaku Keluarga Terhadap Kejadian ISPA pada Balita Di Kelurahan Cambai Kota Ptabumulih. Jurnal Pembangunan Manusia.

PermenkesRINo.1077/MENKES/PER/V/2011

Pedoman Penyehatan Udara Dalam Rumah. Jakarta 
Ramadhaniyanti, N Gita, Budiyono dan Nurjazuli. (2015). Faktor Resiko Lingkungan Rumah dan Perilaku yang Berhubungan dengan Kejadian ISPA pada Balita Di Kelurahan Kuningan Kecamatan Semarang Utara. Jurnal Kesehatan Masyarakat, 3(2).

Safrisal. S A, (2017). Hubungan Ventilasi, Lantai, Dinding, dan Atap dengan Kejadian ISPA pada Balita di Blang Muko. ISBN: 978-979.

Saputra S, (2017). Hubungan Penggunaan Obat Anti Nyamuk Bakar Dengan Kejadian Infeksi Saluran Pernapasan Akut (ISPA) Pada Balita Di Puskesmas Pengadang Kabupaten Lombok Tengah. Skripsi, Universitas Muhammadiyah Malang.

Saleh M, Gafur dan Aeni S, (2017). Hubungan Sumber Polutan dalam Rumah dengan Kejadian ISPA pada Balita Di Kecamatan Mariso Kota Makassar, 3(3).

Sofia, (2017). Faktor Risiko Lingkungan Dengan Kejadian ISPA pada balita di Wilaya Kerja Puskesmas Ingin Jaya Kabupaten Aceh Besar, Jurnal Nutrition, 2(1), 43-50.

Susilawati dkk, (2014). Dasar-dasar Kesehatan Lingkungan (Seri Integrasi Islam Kesehatan). Pustaka Almaidah. Makassar

Taarelluan,T Kusanto, (2016). Hubungan dan Sikap Masyarakat Terhadap Tindakan Pencegahan Infeksi Saluran Pernapasan Akut Di Desa Tataatan 1 Kecamatan Tondano Selatan Kabupaten Minahasa, Jurnal Kedokteran Komunitas dan Tropik, 4(1).

Toanabun, A. H. (2003). Pengaruh Kondisi Lingkungan Fisik Rumah dan Perilaku Penduduk terhadap Kejadian Penyakit ISPA pada Anak Balita di Desa Tual Kecamatan Kei Kecil Kabupaten Maluku Tenggara Propinsi Maluku.

Wahyuningsih S, Raodhah S, dan Basri S, (2017). Infeksi Saluran Pernafasan Akut pada Balita di Wilayah Pesisir Desa Korew Kecamatan Sanggar Kabupaten Bima, 3(2).

World Health Organization, (2012). Data and Statistics.

Wulandani S, (2019). Analisis Faktor Risiko Kejadian Infeksi Saluran Pernapasan Akut ditinjau dari Lingkungan Fisik, Jurnal Sainsmat, 7(2).

Winardi W, Umbo J.M.L, dan Rattu A.J.M, (2015). Hubungan Antara Kondisi Lingkungan Rumah Dengan Kejadian Penyakit ISPA Pada Anak Balita Di Wilayah Kerja Puskesmas Sario Kecamatan Sario Kota Manado.JIKMU, 5(2), 1-13.

Zairinayati dan Putri D H, (2020). Hubungan Kepadatan Hunian dan Luas Ventilasi dengan Kejadian ISPA pada Rumah Susun Palembang, Indonesian Journal for Health Sciences, 4(2), 121-128. 